\title{
NOTES ON THE INSECTS OF BARBADOS, ST. VINCENT, THE GRENADINES, AND GRENADA. ${ }^{1}$
}

BY AUSTIN H. ClARK, BOSTON, MASS.

THE island of Barbados is unique among the islands of the Lesser Antilles in being truly oceanic in the sense of not having had any land connection since the introduction of its present - comparatively speaking - meagre fauna. It differs from all the other islands in being flat, and superficially of coral formation, and is separated from them by soundings of between 1000 and 1500 fathoms, while the nearest (St. Vincent and St. Lucia) are about roo miles away. The fauna is wholly made up of common and generally distributed West Indian types, except where, as in the case of some of the birds, prolonged isolation has given rise to forms different from, though closely related to, others on neighboring islands. In the case of the insects they have been brought there either by winds or on floating wood, etc. Of course many have been accidentally introduced by man. There is no other island in the world so highly cultivated as Barbados, the forest having everywhere given place to the cane field; and this doubtless accounts for the paucity of its lepidopterous fauna to some extent.

The economic entomology of this and the other West Indian Islands has received considerable attention from the Imperial Department of Agriculture for the West Indies, and is dealt with in their periodicals, the "West Indian Bulletin," and the "Agricultural News," both published at Bridgetown, Barbados.

'The butterflies observed here were very few, both in species and in numbers, although I have visited the island at all seasons of the year. The commonest is Callidryas eubule. Others frequently seen are Agraulis vanillae, Junonia coenia, Colaenis julia, Eurema lisa (?), E. elathea (?), several Lycaenas, and a number of skippers. Pontia monuste and Anosia plexippus are occasionally met with.

St. Vincent is high and rugged, with a large area of forest; in fact only the lower parts of the river valleys have been cleared of trees. In the woods, along the mountain paths, Papilio polydamus is very common, the larvae feeding on various species of wild Aristolochia. This species on St. Vincent appears to be above the average in size, with more yellow on the wings than in specimens from other localities. It is very abundant, and is sometimes found on the lower levels. I was surprised to find Dione juno common in the St. Vincent woods, taking the place of Agraulis vanillae of the lowlands. There is a very large brilliant blue Thecla common in the highlands, and on one of the mountain ridges I obtained a freshly

\footnotetext{
1 These notes were made during a recent visit to the islands, beginning in July, 1903, and ending in September, 1904.
} 
emerged specimen of Rothschildia splendens. On the lower lands I found Colaenis julia, Callidryas eubule, Agraulis vanillae, Eurema lisa, E. elathea, E. albula, Eudamus proteus and others of that group, various Lycaenas (including Hemiargus hanno) and a number of skippers common. Pontia monuste and Anosia plexippus occurred, but were not abundant; Anartia jatrophae was common about Kingstown, Junonia coenia was numerous in all the hotter and more desolate districts, and I saw three specimens of Hypolimnas missippus, one (a female) on November 6th, I903, another (also a female) on November $9^{\text {th }}$, and a male on November roth. The first was on Kingstown Hill, and the other two in the Botanic Garden. 'This insect is rather rare on St. Vincent; the protective coloration of the female is here of not the slightest use, as there is no other butterfly anything like it, and this may account for its not gaining a foothold in these islands.

On October 2 nd, I903, I ascended the Soufrière, which very recently (19021903) has been in active eruption. The vegetation on the volcano, and all about it, in fact over almost the entire northern third of the island, has been entirely destroyed, the district now being merely a desert of light brown ash and scoria. About the base and up the sides of the mountain the "Guinea grass" has begun to grow again, and farther down there are large numbers of castor oil plants. About one fourth of the way up from the leeward side there is a patch of bananas, and by the side of it a patch of sugar cane which have come up through the thick covering of ejecta, and mark the site of what was once somebody's garden. They are quite conspicuous, being the only signs of plants of any size on that part of the mountain.

As one looks from the crater of the volcano down on the devastated Carib country toward Georgetown, the thin covering of Guinea grass gives the landscape a fresh, green appearance, and it is hard to realize that not long ago in this very district two thousand lives were lost by an outburst from this mountain. Some mosses and an occasional fern may be found now in sheltered spots inside of the "new crater" which broke out in eruption in $\mathbf{r} 8 \mathbf{r} 2$.

Insects of various kinds are very common all the way to the summit, being rendered especially conspicuous by the lack of vegetation. Of butterflies, Vanessa cardui was almost the only kind seen, but this was very abundant, collecting on the bits of chewed sugar cane and slivers of cane rind thrown down by the porters of parties which had recently made the ascent. These butterflies were found even on the rim of the crater; and their oceurrence was particularly noticeable, as I have never seen the species at any other point on St. Vincent, nor on any other of the West India Islands (including Trinidad) although very likely it is found occasionally. I never saw it in Venezuela, although in parts of that country the conditions are somewhat like those existing to-day in the northern part of St. Vincent. 
One example of Callidryas eubule was met with near the summit, flying before the strong northeast wind, and near the same place I found a dead skipper. Most of the insects seen were Hemiptera, the commonest being the black and red "cottonstainer." There were also many of the yellow-brown wasps (Vespa?) known locally as "Jack Spaniards." About the rim of the crater, more especially along the southern side, there were hundreds of dead insects (mostly Hemiptera) which had apparently been killed by the sulphurous fumes which are continually pouring out.

As a whole, St. Vincent is rich in insects when compared with Barbados, although there do not appear to be many moths. I found Utetheisa abundant, as on all the islands I visited, but only saw one Noctuid. The absence of the Heliconidae and other similar families is noticeable, as one would think that the hot and damp valleys of this island would offer special inducements to them; and such a great number is found in Trinidad that it is rather strange none have strayed up here, or been accidentally introduced. The mole crickets (of which there are two species here) are a serious menace to agriculture, being exceedingly abundant, probably as a result of the introduction of the mongoose, which has killed off a large ground lizard which is said to feed on them.

The "screw-worm" fly (Compsomya) occurs, but is not very common. I only observed it once. On the neighboring island of St. Lucia it is numerous, and a great pest to the stock raiser. It is locally supposed to have been brought into that island by ships carrying mules from the Southern States to South Africa.

A brilliant steel blue mosquito, peculiar to St. Vincent, is abundant in the forests, being found everywhere, but I never met with it in the lower altitudes.

On the Grenadines, the lowland butterflies of St. Vincent are common; on Bequia and southward Cystineura hypermnestra is abundant in the dry woods, and on Canouan we first meet with Phoebis argante, which is common from that island to the continent of South America. Pontia monuste is the commonest butterfly of the Grenadines, although not at all abundant on St. Vincent. There are no Papilios, and the large blue Thecla and Dione juno do not occur, although the latter reappears on Grenada. The "Jack Spaniard," so abundant on Barbados and St. Vincent, building its nest everywhere under the eaves of houses, under the sills of windows, about the mouths of caves, or under the branches of trees, does not occur on Union Island, although it is very common on Mayreau and the northern Grenadines. The islands to the south of Union are free from this species also, but another wasp, a small black insect with white abdominal bands, known locally as the "maribunta," is common on Grenada ; it builds a large nest, usually rather high up in the trees.

Mosquitoes are exceedingly abundant on the Grenadines, especially in the 
lowlands of Carriacou; and unless a person travels with a net, sleep is almost impossible. They appear during the wet season, from June to November.

The parasol ant or "gros-tête" is numerous on Carriacou, where it was probably introduced from Trinidad by small trading boats plying between the two islands, as it doès not occur on the other Grenadines, nor on Grenada. This insect is a great pest, making it impossible to raise roses and a number of garden vegetables and other plants. It is very fond of the flowers of the red hibiscus.

On Carriacou also there is a large millipede, locally called the "congeree," which appears here to have reached the northern limit of its distribution. It is very common on the higher lands, and a banana or mango skin thrown down anywhere soon becomes a mass of them.

The butterflies noticed on Grenada were the same as those on St. Vincent, with the addition of the two species (Cystineura hypermnestra and Phoebis argante) which do not extend farther than the Grenadines, and also Historis odius and Avartia amathea. Papilio polydamus and the large blue Thecla of St. Vincent are lacking. Erebus odora and Herse cingulata are common here, and on Carriacou, and very likely on St. Vincent as well, although I did not find them on that island.

The object of my trip to these island was to make a study of the birds, and I unfortunately found it impossible to bring back a collection of insects; but I am sure that this region, where the South American fauna meets the West Indian, would yield most interesting results to the student of geographical distribution in insects, as it has in regard to its birds and mammals; besides which a host of new forms would be brought to light, as shown by the results of collections which have been made on St. Vincent and on Union Island. 

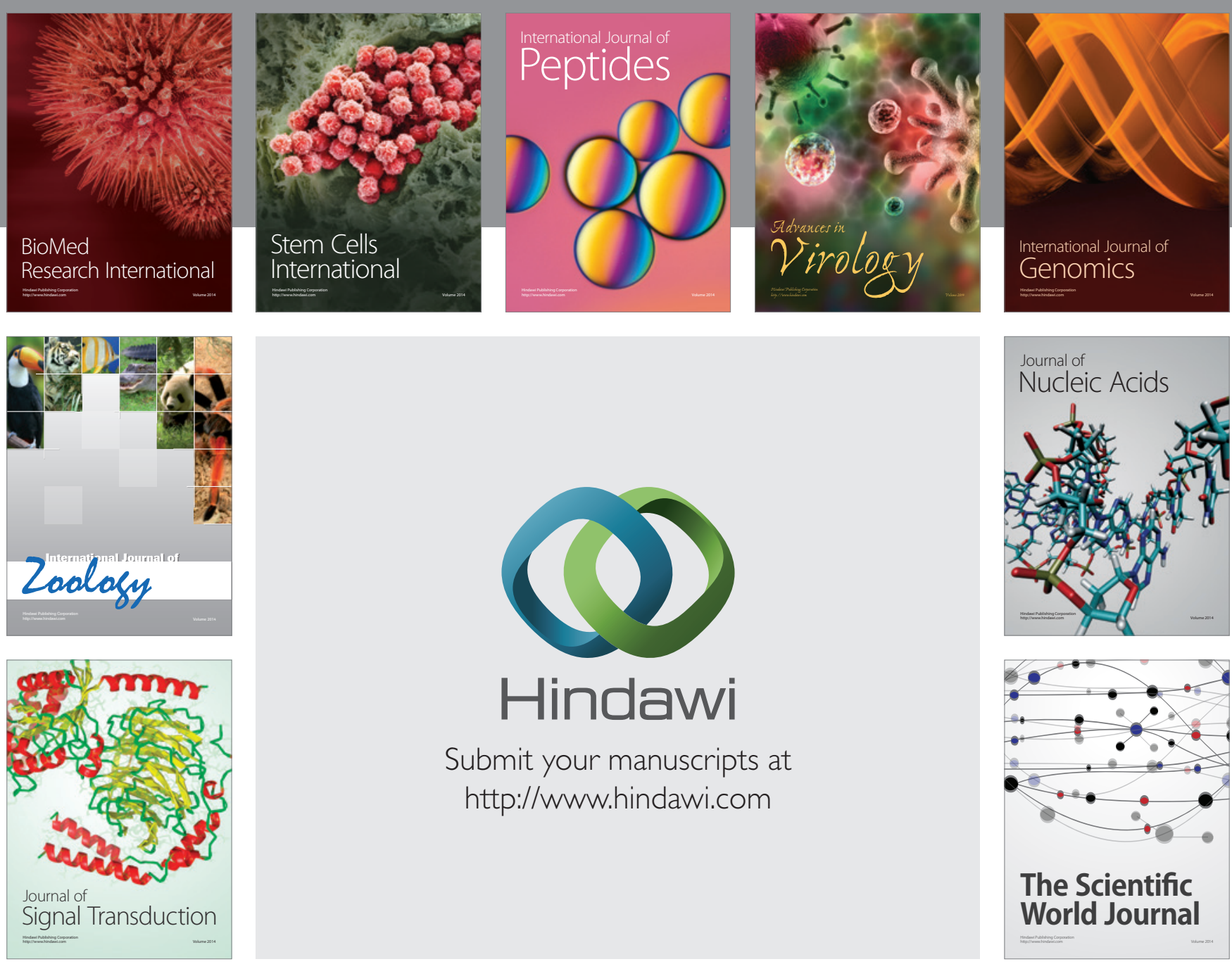

Submit your manuscripts at

http://www.hindawi.com
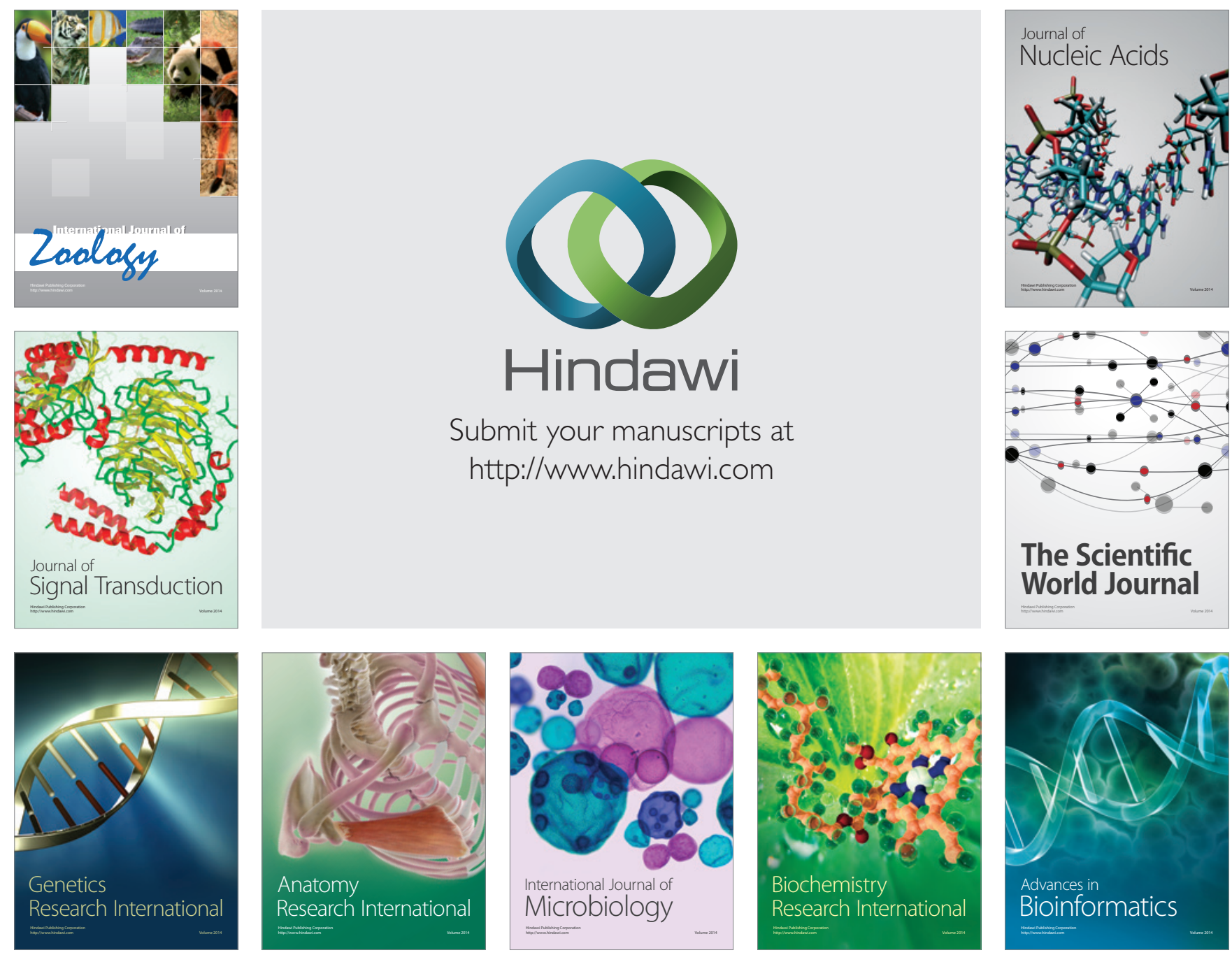

The Scientific World Journal
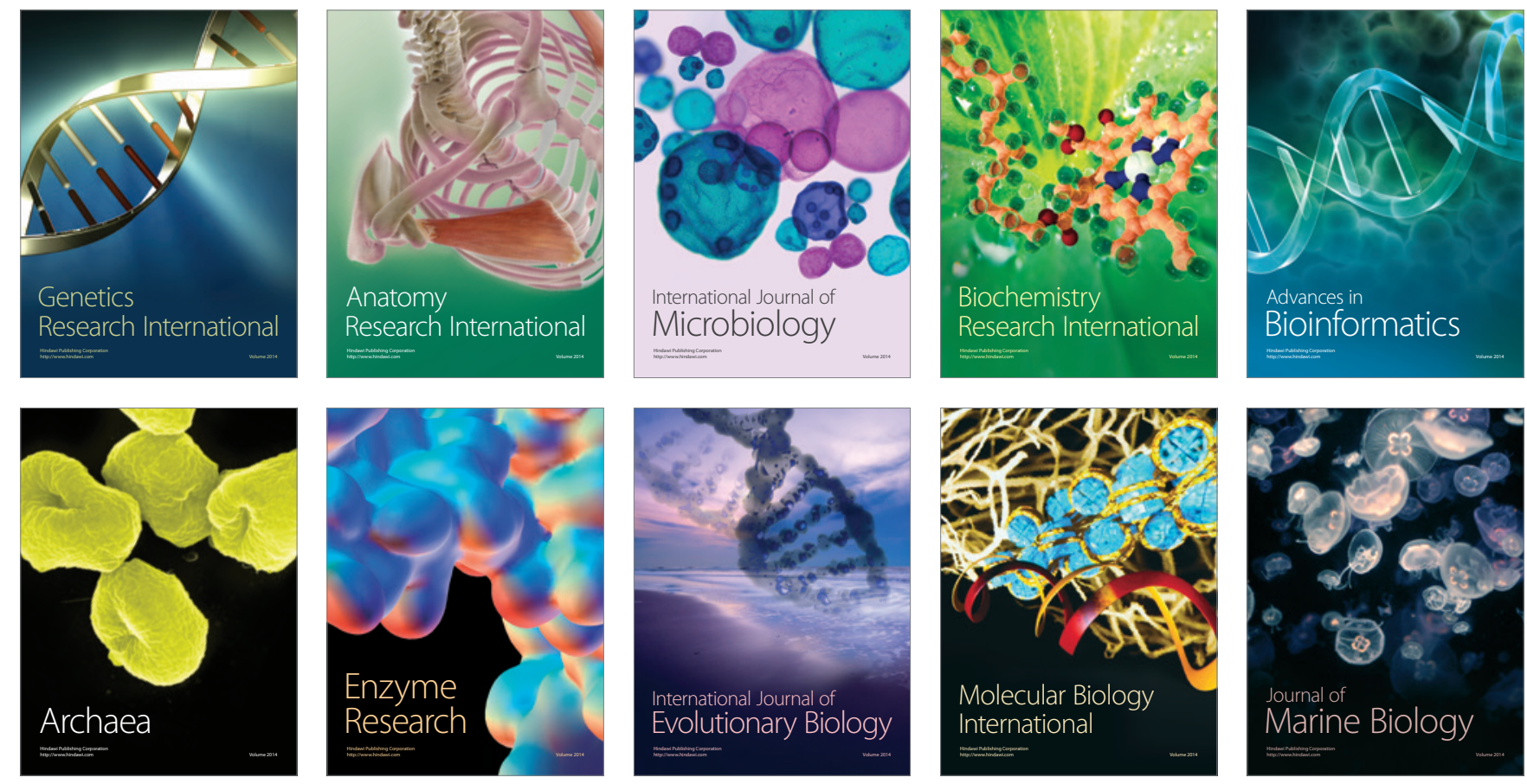